\title{
STRATEGY IMPLEMENTATION OF NATIONAL EDUCATION STANDARDS AT THE POTENTIAL JUNIOR HIGH SCHOOL IN BANDUNG
}

\begin{abstract}
Yusuf Arifin
Abstract

The purpose of this study was to determine 1) the condition of the existing SMP potential in achieving the National Education Standards (SNP), 2) analyze the gap / gap between the real conditions Potential SMP with National Education Standards, 3) formulate an implementation strategy of the National Education Standards to Potential Junior High School. The unit of analysis in this study is 6 Potential Secondary Schools in the city of Bandung, which are in cluster 1 (1 Junior High School), cluster 2 (2 Junior High School) and cluster 3 (3 Junior High Schools). The results showed the level of the gap between the real conditions Potential Secondary Schools in Bandung with National Education Standards are as follows: standard financing is the largest gap compared with other standard is $59.2 \%$. The next largest gap in a sequence is the standard of infrastructure $(46.1 \%)$, the standard process (39.6\%), the standard assessment $(29.7 \%)$, teachers and education personnel standards $(25 \%)$, the standard management $(23.3 \%)$, content standards $(23.2 \%)$, and the smallest value of the average gap is competency standards $(11 \%)$.
\end{abstract}

Keywords: Strategy Implementation, National Education Standards, Potential Schools.

\section{INTRODUCTION}

One implication of the regional autonomy implementation is decentralization of education which is emphasized in School Based Management (MBS) as a strategy to improve the quality of education is assumed. Given the implementation of the MBS system allow for variation in many respects, to encourage transparency and public accountability in the implementation of the national education system, National Education Standards Agency (BSNP) has established eight (8) national standards for the quality of education as a reference (benchmark) to spur managers, organizers and education units in order to improve its performance in delivering quality education. The policy is set by government in Government Regulation No. 19 of 2005 on National Education Standards.

In the national education system, the quality assurance of education includes two approaches. First, the external quality assurance is done by various parties / institutions outside the formal educational unit has duties and functions related to quality assurance in education either directly or indirectly. Second, the internal quality assurance carried out by each school. Both models approach, has been linked to one another, including the linkages between external institutions in question.

In the concept of autonomy in practice education, the school is a major actor of education quality assurance. Education quality assurance process begins each school to formulate the vision, mission, and goals for the school and to develop a strategic plan and annual operating plan that is comprehensive attention to the opportunities and threats of the external environment and internal strengths and weaknesses and determine strategies and programs. One of the instruments to assess quality improvement in a comprehensive set of education is school self-evaluation (EDS). Through the process of school self-evaluation will be found 
gaps in school performance and fulfillment of Minimum Service Standards (SPM) and SNP can be used as an accurate basis as a future development.

Related to the achievement of the SNP, the government has issued Regulation of National Education Minister (permendiknas) No. 15 Year 2010 on minimum service standards (SPM) education. In the context of improving the quality, has a function to create phasing of SPM efforts to improve input, processing and management of education services in a systematic and balanced so that the achievement of quality education in accordance SNP approach can be realized through the most effective and efficient. The presence of SPM, the government hopes from 2014 all basic education schools in Indonesia has been able to achieve a quality suitable SNP.

When the government targeted to achieve $100 \%$ of schools nationally standardized had 2 (two) years ago, while the target has been reached is still around $31 \%$. Researchers assume that secondary schools in the city of Bandung not yet at $100 \%$ SSN, as announced by the government. It is therefore necessary to study science related implementation strategies of eight (8) national standards of education at junior high school in Bandung potential, given the quality of the output secondary education has contributed greatly to the quality of educational inputs the next level.

\section{Research Focus}

The results of empirical observations and conceptual, national quality assurance standards of education as a form of school accountability, has not been done properly in the Junior High School in Bandung. Although the results of the entire Junior High School Bandung A rank in school accreditation. Conceptually, accreditation ratings indicate that the school has met or even exceeded eight aspects of SNP. Accreditation rating B indicates that the school has met SNP and exceeded some aspects of SPM. And accreditation ratings $C$ indicates that the school has met the SPM.

Seen by category, out of 52 junior high school, 38 of them or $73.1 \%$ are still in a potential category. Ministry of Education (2007:4) states that the school basically has the potential aspects of National Education Standards, but in terms of content, scope, extent, quantity and quality aspects of the National Education Standards are still under the SNP. It is necessary for strategic efforts related to compliance with the SNP.

\section{Problem Formulation}

Description of the focus of the study on the basis of researchers to formulate research problem as follows:

1. How is the gap between the real conditions Potential Secondary Schools in Bandung with National Education Standards?

2. How the National Education Standards implementation strategy on the Potential Secondary Schools in the City of Bandung?

\section{Research Objectives}

1. In particular, this study aims to reveal or describe information related to:

The gap between the real conditions Potential Secondary Schools in Bandung with National Education Standards. 
2. Formulate implementation strategies National Standards in Secondary Schools Education Potential in Bandung.

\section{Usability Research}

\section{Theoretical Uses}

In terms of scientific research is expected to increase the repertoire of scientific importance of the application of innovative management theories as a strategy for implementation of national education standards in order to improve the quality of education in schools.

2. Practical Uses

a. As input information for educational practitioners (teachers and principals) on implementation of the strategic importance of the national standards in order to carry out quality assurance of education as a form of public accountability.

b. For education stakeholders, as study materials for use referral decisions related to the fulfillment of the National Education Standards.

\section{Thinking Framework}

This study is based on the concept of the school as a system consisting of component inputs (input), process and output (output / outcome).

\section{Input}

is everything that should be available for the continuity of the educational process. include:

a. Input policy: Regional Autonomy, the National Education Standards and School Based Management (MBS)

b. Input expectations: Vision, Mission and Program

\section{Process}

Using a strategic approach to school-based management and quality management, quality assurance processes by analyzing the gap between the real condition of Bandung Potential Secondary Schools with the provisions of national education standards. Stage of the process carried out following the steps set out Dany Meirawan (2010:130) as follows: 1) standard setting, 2) testing / auditing education system is in progress, and 3) inference about the existence of a gap between the existing systems with standard set; 4) If there are gaps then identify the steps taken in an effort to meet the needs of established standards; 5) Proceed with the development of improved systems and repair systems integrate with existing systems is in progress, 6) but if there is no gap reexamination compliance with the standards adopted the system on an ongoing basis.

Output

The results of the gap analysis (gap) between the real conditions Potential SMP Bandung with SNP subsequently used as the basis for SNP implementation strategy. The formulation of the strategy is to be the output of this research.

\section{Outcome}

Fulfillment of SNPs are expected to provide feedback to improve the quality of education of potential category school in accordance with SNP, so the school accountability is accountable both administrative and public. 
64 Arifin, Strategy Implementation Of National Education Standards At The ...

\section{Methodology}

Methods The studyused a qualitativemethod, the researchstages as follows:

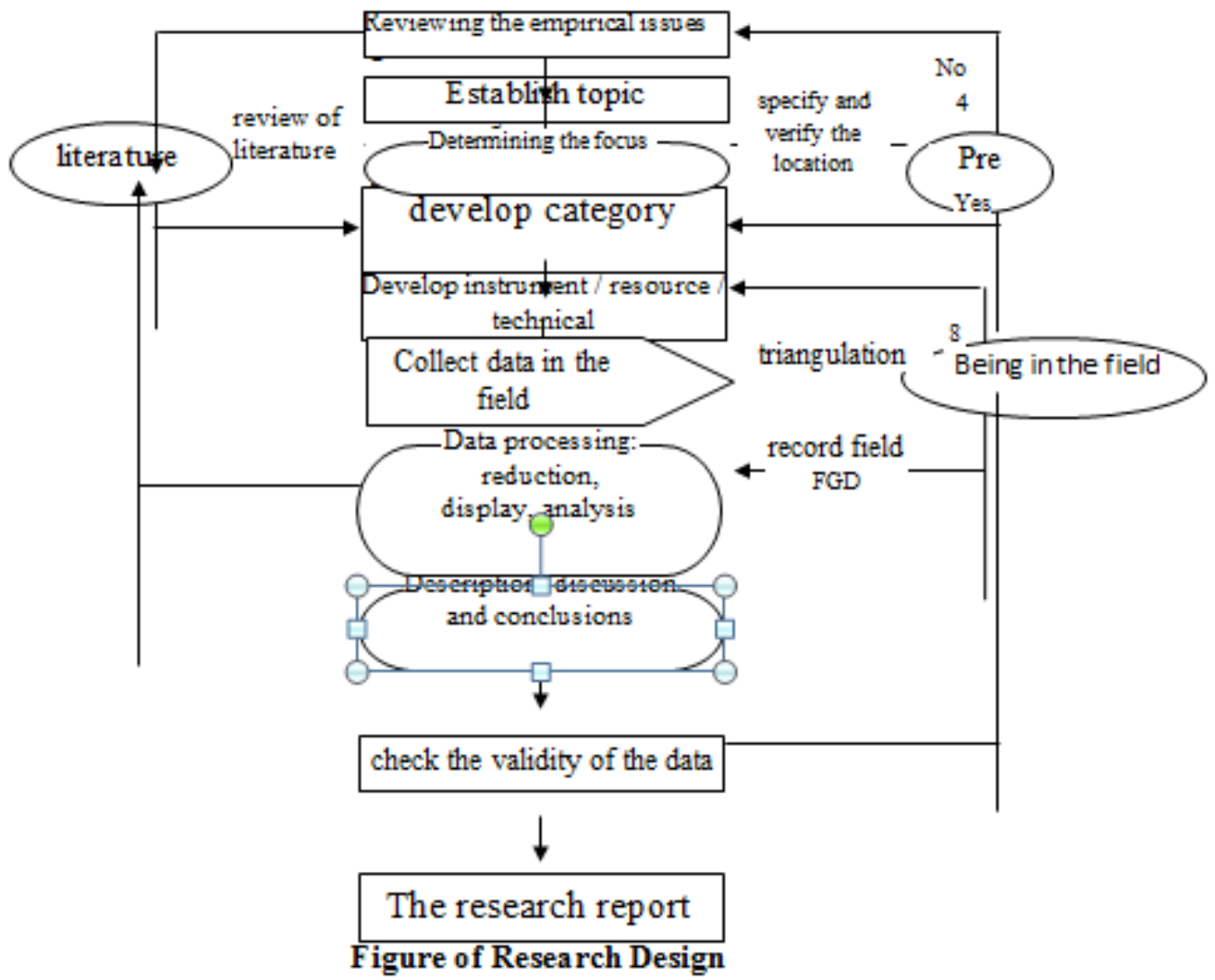

\section{Results}

The results of the analysis of qualitative and quantitative data using EDS instruments on eight SNPs on Potential Secondary Schools in Bandung is as follows (can be seen in chart 1 and 2):

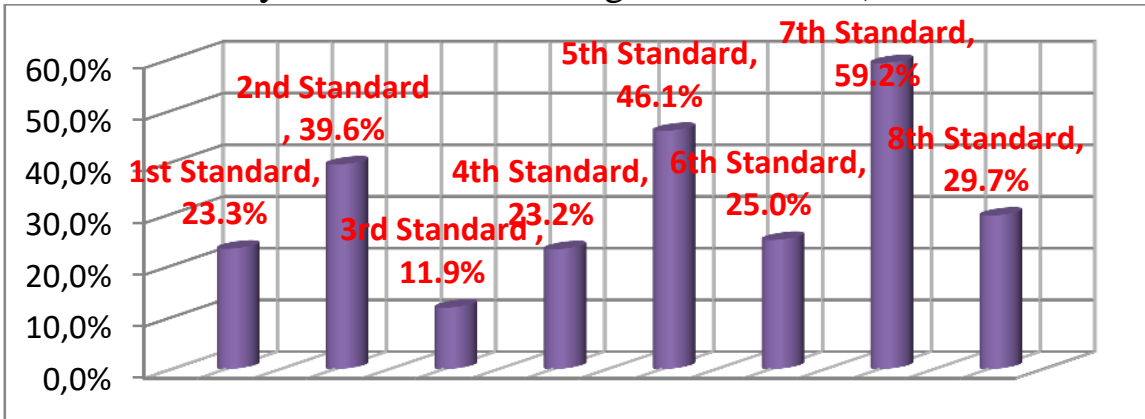

Figure 1: Graph of Average Achievement Gaps SNPs in Bandung

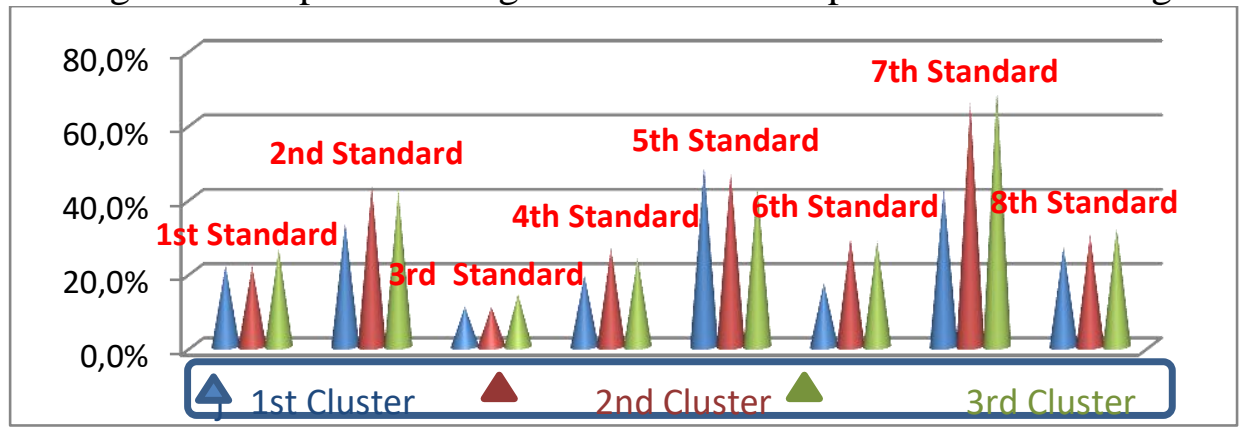

Figure 2: Graph Based Cluster SNP Achievement Gaps 
Figure 1. indicates that the funding standard is the largest funding gap compared to other standards. The next largest gap in a sequence is the standard of infrastructure, process standards, assessment standards, teachers and standards, management standards, content standards, and the smallest value of the average gap is competency \& graduation standards.

\section{Content Standard}

In cluster 1 and 2, the rate of significant gaps in how schools provide for students' personal development, especially on the counseling service. This aspect is merely the planning, implementation and evaluation, not to maximize on other things, such as career development, the consideration of the potential for an individual case, and facilitating the development of self-minded international students. In particular, the three clusters are very visible once the counseling role is still known as a "troubled students".

\section{Standard Process}

The biggest gap is in cluster 2. The gap in this standard is the school factor in implementing supervision was incidental and not done at all with the teachers are implementing vice principals. The results of the supervision has not been followed up.

\section{Competency and Graduation Standard (SKL)}

In clusters 1 and 2 have high levels of inequality are not too different, while significant levels of inequality found in cluster 3 , in particular on those aspects that are more educational outcome, which shows the progress of students as independent learners, motivated to learn and taste high confidence, life skills, and to develop virtue and commendable. In general, only limited achievement of SKL graduation rate> $90 \%$ and national test scores.

\section{Teachers and Education Personnel Standard}

There is still a gap averaged $23.2 \%$. Factors affecting the occurrence of a gap, namely:

1. The number of subject teachers as needed (advantages / disadvantages).

2. Unavailability of counseling teachers appropriate student ratio

3. The academic staff do not have the required certificate of competency.

\section{Infrastructure Standard}

The gap in the standard is quite large which is about $46.1 \%$. The biggest gap is in cluster 1 , and this is the main cause of school cluster 1 is not a national standard schools. The gap is affected by:

The number of classes that average over 24 study groups, the number of students in study groups beyond the standard 32 students. And all the schools still contain approximately 38-44 students each study group. It is also one of them caused by the availability of buildings and land owned by the school. School is hard to reduce the quota of new admissions to match the standard on the grounds of compulsory education. As a result, many schools still time to study two (2) shifts, whereas in the standard number of classrooms should be equal to the number of study group, so that the school schedule was not made into two shifts, morning and afternoon.

\section{Management Standard}

There is still a gap averaged $25.0 \%$. Two factors influence the occurrence of gaps sorted from the largest, namely: 
1) Lack of support and professional development opportunities for educators and education personnel.

2) Performance management has not been based on teamwork and strong partnerships to achieve fulfilling their vision and mission of the school. The process of school management has not been fully implemented independently, participatory, collaborative and accountable.

\section{Funding Standard}

Standard being the largest financing gap, and the largest was at school cluster 3 . The gap is due to the following factors:

a. the majority of schools do not build networks with the Business and the World Industries (DUDI) local, also with alumni, either in the form of ideas, energy, funds and infrastructure. Schools do not have the capacity to raise funds on its own initiative. Schools rely on government funding in the form of School Operational Assistance (BOS), both central and BOS BOS area. Though the opportunity to access funds from the corporate world in the form of Corporate Social Responsibility (CSR) is great for education. But not a single school that attempted to access the fund.

b. Financial transparency. Most of the new schools provide financial reports to the funders that in this case the government, the report has not been accustomed to be forwarded to other stakeholders and to the school.

\section{Assessment Standard}

There is a gap in clusters 1, 2 and 3 on the aspects of impact assessment in the learning process. Assessment by the educator in question are (1) to provide input and comment on the assessment they do to students, (2) use the results of assessment to improve learning. New student assessment results be used to improve the learners who have achieved competence to carry out tests and remedial learning, not to be used for the improvement of teaching methods and the progress of the study of students, while the students who have achieved competence is still not given the task of developing the material.

\section{CONCLUSION AND RECOMMENDATIONS}

National Education Standards are understood not equal among the various parties, ranging from the level of education up to the level of education unit / school. Establishment of national education standards that direct school potensial achieved National Standard of Education in an attempt to guarantee the quality of national education, is still understood by some staff in Bandung city education office as a project of the central government to block grantnya, and do not regard it as a joint task of the central government, provinces and cities to the achievement of quality education.

At the school level, the national standards or the National Standards School just considered as "labeling" school to improve school image in the public opinion. Although the schools understand the SSN as an effort to improve the quality of education at the school, but for the management of the implementation of achievements has not been dealt with in a structured school strategy and focused. Schools had enough and resigned to the existing conditions 
without much effort to achieve it. As SMPN 8, because it is hampered by land area, and the excessive number of classes and number of students, find it difficult to reduce the quota because the consequences are difficult to deal with. So take a solution to improve the quality of learning through service learning to students better, by providing a complete IT facilities in every classroom.

Accreditation is a quality assurance instrument of education, but for a better quality of education is not enough to just get the value of accreditation A. From this study the value of accreditation is not proportional to the achievement of national education standards. The evidence is clear almost all or the majority of the Junior High School in the city got an A for accreditation, but in the achievement of national education standards are still very far from the expectations of the government $100 \%$ of SSN in 7 years since the issuance of Government Regulation No. 19 of 2005.

Regional Autonomy which was born during the reform through Law No. 32 of 2004 on Regional Government can not make the world a better quality education. Autonomy impressed simply move the problem from central to local level. Increasingly difficult to develop the quality of education, because education follow the politics of being the object of local elites. It appears in the study authors in the field and when the informant interviews. They do not feel an improvement with decentralized education. The opposite happened. For example, what happens after the decentralization of education is the excessive interference of the political elite, including the education of students in the process of receiving new and equally impact is in terms of financing, BOS disbursement is often too late, especially after the redemption through the city. So the difficulty in funding schools and when disbursements are late, make the most of the funds are not absorbed, and the difficulties encountered in the reporting. Directly they expressed the opinion that they could not agree when returning to a centralized system of education.

The results showed that the standard is the largest funding gaps in comparison with other standards. The next largest gap in a sequence is the standard of infrastructure, process standards, assessment standards, teachers and standards, management standards, content standards, and the smallest value of the average gap is competency and graduation standards.

The results are quite phenomenal, where the government is allocating large budgets for education, it turns out the standard achievement level funding in junior high schools become the largest gaps. Having studied more in depth in this financing gap on factors such as the school has not yet built a network of cooperation with business and industry, alumni, donors at home and abroad. This could be due to already have enough with government funding, or because the ability is not visionary school leadership in order to develop even more advanced school, so the school does not have sufficient capacity to raise funds on their own initiative.

The amount of the education budget for schools is not matched by financial transparency. From this study it was found that financial reporting has not been forwarded to the entire school community, only limited to the funder in this case the government in accordance with the flow and existing mechanisms. Still found no-confidence vote from the school community (teachers, students, and parents) to BOS fund management in schools.

Based on the results of the study, researchers gave advice to the relevant parties to participate achieving success together so that schools can achieve the national standard as targeted by the 
government, which is 7 (seven) years from the issuance of Government Regulation No. 19 of 2007.

\section{Bandung City Department of Education}

Position of the school is the Regional Technical Implementation Unit under the responsibility and Coordination Department of Education Bandung. So it is very necessary understanding of the education equation on the national standards of education. Central government policies should be in line with government policy despite the decentralization of education.

Decentralization of education is not expected to make education worse off due to the quality of education being the object of politics involved regional elites. Schools should be given authority without interfering in technical matters such as in the case of New Students Admission (PPDB).

\section{The entire school community and stakeholders.}

There should be good cooperation between all the citizens of the school and its stakeholders. Good cooperation between the principal, vice principals, teachers, school committees, and alumni are organized can be an incredible force in helping to make a quality school.

\section{For further research}

This study is expected to be continued in more detail the scope of a broader unit of analysis, eg, by taking the entire school junior high school in the city of Bandung, or perhaps in the province and across Indonesia.

\section{REFERENCES}

Akdon, 2009, Strategic Management for Educational Management, Alfabeta, Bandung

Armida S. Alisyahbana, 2000, Autonomy and Decentralization of Education, FE Unpad, Bandung

Djam'an Satori and Aan Komariah, 2010, Qualitative Research Methodology, Alfabeta, Bandung

Ernie Tisnawati Saefullah Sule and Kurniawan, 2010, Introduction to Management, Kencana Prenada Media Group, Jakarta

Ibrahim Bafadal, 2007, Fundamentals of management and supervision of kindergartens, Bumi Aksara, Jakarta

Indra Bastian, 2007. Accounting education. Bandung: Erlangga

Ministry of National Education, 2010, Guidelines for Education Quality Assurance System

Lexy J. Moleong, 1999, Qualitative Research Methodology, PT. Remaja Rosdakarya, Bandung

Lexy J. Moleong, 2001, Qualitative Research Methodology, PT. Remaja Rosdakarya, Bandung

Nana Fatah, 2002, Economics and Financing of Education. Rosda Kerja, Bandung

Nawawi, Hadari (2000), Strategic Management of Non Profit Organizations In the area of Governance, with Illustrations In Education, Gadjah Mada University Press, Yogyakarta.

Pearce, John A and Robinson, Richard B, 2009, Strategic Management-Formulation, Implementation, and Control, 10th Edition, Salemba Empat, Jakarta 
Bandung City Government (2009), Medium-Term Regional Development Plan 2009-2013 Bandung

Sallis, Edward, 2010, Total Quality Management in Education: Educational Quality Management, ORCiSoD, Jogjakarta

Sobarsa Kosasih, 2009, Operations Management, Jakarta: Mitra Wacana Media

Sondra P. Siagian, 2008, Strategic Management, Bumi Aksara, Jakarta

Suad Husnan, (1992), Financial Management: theory and application, Yogyakarta BPFE

Supriadi D, 1998, Scientific Truth, the Scientific Method, and the Paradigm Research Personnel, PPS Teachers' Training College (IKIP), Bandung

Syaiful Sagala, 2007, Strategic Management Education in Quality Improvement, Alfabeta, Bandung

Umiarso, Imam Gojali, 2010, Quality Management in the Era of Autonomous School of Education, ORCiSoD, Jogjakarta

Veithzal Rivai, 2009, Education Management: Theory and Practice Analysis, Rajawali Press, Jakarta

Weelen, Thomas L and Hunger, J. David, 1995, Strategic Management and Business Policy, Addison-Wesley Publishing Company.Inc.

\section{JOURNAL}

David Wijaya, 2009, Implications of Financial Management on the Quality of School Education, Journal of Education Sower - No.13/year 8/Desember 2009

\section{COLLECTION OF REGULATION:}

Government Regulation No. 19 of 2005 on National Education Standards

Government Regulation No. 48 of 2008 on Education Funding

Government Regulation No. 47 of 2008 on Compulsory Education Law No. 20 of 2003 on National Education System

Regulation of the Minister of National Education No. 24 of 2007 on Infrastructure Standards

Regulation of the Minister of National Education No. 29 of 2009, regarding Standard Operating Expenses Non Personnel

Regulation of the Minister of National Education No. 63 of 2009 on the Education Quality Assurance System

Regulation of the Minister of National Education No. 15 of 2010 on Minimum Service Standards for Basic Education in District / City

National Education Standards Agency, 2006, Standard Facilities and Infrastructure Education / General Education Madrasah

\section{COLLECTION OF ARTICLES AND PAPERS}

Department of Education (2011), National Standards List Junior School West Java, hhtp / / www.dit-plp.go.id/ssnsbi/daftarssn0409

http://edukasi.kompas.com/read/2011/03/23/10321298/ Downloaded on 2 April 2011

Ministry of National Education, 2011, Education Role in Strengthening National Competitiveness

Satria Dharma, 2010, "Critics Top International School Program (SBI) and the proposed repair the" Papers, http://satriadharma.com/index.php/2010/11/03/

Armida S. Alisjahbana, 2000, Autonomy and Decentralization of Education, FE UNPAD, Bandung 
64 Arifin, Strategy Implementation Of National Education Standards At The ...

COLLECTION OF THESIS:

Henry Kuswandi, 2003, Effect of managing Facilities / Infrastructure, Man Power, Public Relations at the School of Management Implementation of School-Based Quality Improvement (MPMBS) of the Service Learning, Education University of Indonesia, Bandung

Yopti Nugraha, 2003, Tuition Assistance Management and Continuity of Operation Impact on Education, UPI, Bandung 